\section{Weed and Crop Response to Colored Plastic Mulches in Strawberry Production}

\author{
Mark S. Johnson ${ }^{1}$ and Steven A. Fennimore ${ }^{2,3}$ \\ Department of Vegetable Crops, University of California, Davis, 1636 East \\ Alisal Street, Salinas, CA 93905
}

Additional index words. Fragaria $\times$ ananassa, photosynthetically active radiation, soil warming, plastic mulch, weed growth, weed germination

\begin{abstract}
The phase out of methyl bromide has forced strawberry (Fragaria $\times$ ananassa Duchesne) growers to consider the use of cultural methods such as colored mulches to enhance weed control. Black plastic mulch controls most weeds; however, black mulch often does not warm the soil as well as clear mulch. Soil warming with clear mulch is desirable for early season markets, but clear mulch does not control weeds. Neither black nor clear mulches combine the ideal weed control and soil warming characteristics required. Seven colored mulches, as well as clear, black and no mulch were evaluated in California organic and conventional strawberries to identify mulch factors associated with weed control and soil warming. Laboratory and greenhouse experiments were also conducted to isolate the effects of light transmittance through mulch on weed germination and growth. The effect of mulch color on transmittance of photosynthetically active light (400 to $700 \mathrm{~nm}$ ) through mulches was the key weed control factor, and was more important than the effect of mulch color effect on weed germination. Satisfactory weed control was provided by all mulches except clear, blue and red-brown laminated. Clear and black mulches provided the greatest soil warming in sunny and cloudy climatic conditions, respectively, although plants in clear mulched conventional production system plots produced the highest yield of marketable berries. Green and brown plastic mulches provided the best combinations of soil warming and weed control benefits at all trial locations.
\end{abstract}

California's central and southern coastal districts are the most productive strawberry (Fragaria $\times$ ananassa Duch.) growing areas in the United States [National Agricultural Statistics Service (NASS), 2002]. There are about 11,500 ha of strawberries grown in California, of which 4,200 ha are grown in the Watsonville and Salinas district [California Strawberry Commission (CSC), 2001]. Most California strawberries are planted annually in soils previously fumigated with methyl bromide and chloropicrin. This annual planting system utilizes productive varieties, raised beds, drip irrigation and plastic mulches [U.S. Department ofAgriculture(USDA), 1999]. Methylbromide and chloropicrin are the basis for control of plant pathogens, nematodes, soilborne insects and weeds (Wilhelm and Paulus, 1980). The Montreal Protocol requires the phase out of methyl bromide in the United States by 2005 (United nations Environmental Programme,

Received for publication 5 Nov. 2004. Accepted for publication 16 Jan. 2005. We thank the California Strawberry Commission and the University of California, SAREP for financial support, as well as Clyde Elmore, Tom Lanini, Steve Enloe and Frank Martin for their help and suggestions. Mention of trade names or proprietary products is for the convenience of the reader only, and does not constitute endorsement or preferential treatment by the University of California.

${ }^{1}$ Formerly Dept. of Vegetable Crops and Weed Science, currently Johnson Farms Gridley, Calif.

${ }^{2}$ Dept. of Vegetable Crops and Weed Science.

${ }^{3}$ To whom reprint requests should be addressed; e-mailsafennimore@ucdavis.edu.
1998), thus alternative pest control measures are needed. Without methyl bromide for weed control, alternative fumigants such as chloropicrin and 1,3-D that provide less effective weed control, will be used (Locascio et al., 1997), and will require additional inputs and/or modified cultural practices to achieve adequate weed control. Plasticulture provides a means to augment weed control provided by less effective fumigants. Therefore, a better understanding of the influence of mulch on weed control, and the interaction between weed control and crop yield response is necessary.

Weeds compete with strawberry for sunlight, nutrients, and moisture. Strawberry characteristics such as low creeping growth habit and shallow root system limit its ability to compete with taller and faster growing weeds (Galleta and Himelrick, 1990). Weeds can be alternate hosts of many common strawberry diseases. Hairy nightshade (Solanum sarrachoides Sendter), common groundsel (Senecio vulgaris L.), annual sowthistle (Sonchus oleraceus L.) and shepherd's-purse (Capsella bursa-pastoris [L.] Medic), for example, are hosts of Verticillium wilt (Verticillium dahliae), potentially the most damaging pathogen in strawberry production (Wilhelm and Thomas, 1952, Fennimore, 2005).

The opacity of plastic mulch influences weed control. Black plastic mulch controls weeds because weeds cannot grow in the absence of photosynthetically active light (Olson, 2002; Teasdale and Mohler, 2000). However a yield loss of up to $15 \%$ can be expected with substitution of black plastic for clear plastic in winter production districts such as Southern California (USDA, 1999). Clear mulch promotes winter growth of the strawberry plants necessary for the winter planting system used in the California south and central coast districts (Galleta and Himelrick, 1990). Clear mulch hastens and increases strawberry yields by increasing soil temperature (Voth and Bringhurst, 1959 and 1962).

For strawberry producers, a dark mulch color may provide good weed control, but lower yields, and clear mulch may increase weeding costs, therefore there are no ideal choices between clear and black mulch. Colored mulches that inhibit photosynthetically active radiation (PAR, 400 to $700 \mathrm{~nm}$ ) yet warm the soil and produce higher yields than black mulch are available. The objective of this study was to identify and characterize mulches that controlled weeds and promoted strawberry growth during winter.

\section{Materials and Methods}

Field trial locations and proceedures. Two field trials were conducted during the first season, August2000 throughAugust2001, atcommercial conventional and organic production fields at Watsonville, Calif. In the second season, August 2001 to September 2002, three trials were conducted; two again at Watsonville and a third trial at an organic production site on the USDA field stationnearSalinas, Calif. Strawberries were grownusing an annual hill, winterplanting system on raised beds following commercial practices typical for the area (USDA, 1999). In all trials two drip irrigation lines (Netafim Streamline 60; Netafim, Fresno, Calif.) with emitters spaced 30 $\mathrm{cm}$ apart were buried 2 to $5 \mathrm{~cm}$ deep and $8 \mathrm{~cm}$ from the center on either side of the raised bed. Strawberry cultivars included in these studies were either 'Camarosa' or 'Diamante'. Information pertaining to the soil texture, trial period, cultivar and production system used for each field trial is listed in Table 1. Periodically, canopy diameters from 20 to 30 plants, as noted below, were measured in two dimensions, parallel and perpendicular to the row, and then averaged by plant. Fruit was harvested at weekly intervals from 20 to 40 plants in the middle of each plot during the intervals listed in Table 1. Commercial harvest personnel provided by the cooperating grower, harvested, sorted and weighed marketable and cull fruit. Treatments in all field trials were arranged in a randomized complete block design with four replicates.

Watsonville conventional site. The conventional plot area at Monterey Bay Academy near Watsonville, Calif., had been in continuous strawberry production since 1995. After tillage, $1.4 \mathrm{~m}$ wide $\times 30 \mathrm{~cm}$ high raised beds were formed, and then slow release fertilizer $(27 \mathrm{~N}-10 \mathrm{P}-12 \mathrm{~K})$ was applied at the rate of 400 $\mathrm{kgha}^{-1}$. Chloropicrin (Niklor Chemical, Long Beach, Calif.) at a rate of $209 \mathrm{kgha}^{-1}$ was applied by shank injection $30 \mathrm{~cm}$ deep with two chisels $35 \mathrm{~cm}$ apart on 17 Aug. 2000, and 29 Sept. 2001 and fumigation mulch was applied in the same operation. The fumigation mulch was removed 2 weeks after fumigation, and then the colored plastic mulch treatments were 
Table 1. Field study locations, soil texture, production system, cultivar, plant date and harvest interval.

\begin{tabular}{|c|c|c|c|c|c|}
\hline Location & Soil texture & Production system & Cultivar & Plant date & Harvest interval $^{z}$ \\
\hline Watsonville & Elder sandy loam ${ }^{y}$ & Conventional & Camarosa & 25 Oct. 2000 & 6 Apr. to 9 Aug. 2001 \\
\hline Watsonville & Elder sandy loam & Organic & Diamante & 13 Nov. 2000 & 7 Apr. to 10 Aug. 2001 \\
\hline Watsonville & Elder sandy loam & Conventional & Camarosa & 31 Oct. 2001 & 19 Mar. to 7 Aug. 2001 \\
\hline Watsonville & Elder sandy loam & Organic & Diamante & 15 Nov. 2001 & 7 Apr. to 8 Aug. 2001 \\
\hline Salinas & Chualar loamy sand ${ }^{\mathrm{x}}$ & Organic & Diamante & 15 Nov. 2001 & 9 Apr. to 29 Aug. 2001 \\
\hline
\end{tabular}

${ }^{\mathrm{z}}$ Fruit was harvested at weekly intervals.

y Coarse-loamy, mixed, thermic, Cumulic Haploxerolls.

xFine-loamy, mixed, thermic, Typic Argixerolls.

installed in plots that were one bed wide $\times 19.5$ mlong. Mulches used for this trial include: black (embossed, $15 \mu \mathrm{m}$ ), clear (Polydak embossed, $10 \mu \mathrm{m}$ ), brown (Al Or Brown, $20 \mu \mathrm{m}$ ), green (PST Green, $20 \mu \mathrm{m}$ ), red (Al Or Red laminated on brown, $25 \mu \mathrm{m}$ ), yellow (yellow laminated on brown, $30 \mu \mathrm{m}$ ), and white/black 1 (white laminated on black, $25 \mu \mathrm{m}$ ), made by Ginegar Plastics, Inc., Kibbutz Ginegar, Israel, and blue mulch (embossed, $16 \mu \mathrm{m}$ ), made by Pliant Corporation (Schaumburg, Ill.). At the time of strawberry planting, a 4-inch slit was cut to allow for planting through the plastic mulch, hereafter referred to as the "plant hole". Twice during each growing seasons, 19 Dec. 2000 and 13 Apr. 2001 for season one and 1 Mar. and 20 May 2002 for season two, the canopy diameters of 30 plants from the middle of each plot were measured.

After the mulch installation, Hobo Pro H08 temperature recorders (Onset Computer, Pocasset, Mass. USA) were placed in the first block to record the soil temperature $2.5 \mathrm{~cm}$ deep under the mulch throughout the cropping season. Soil temperature degree-hour accumulations above $10{ }^{\circ} \mathrm{C}$ were calculated as previously described in (UCIPM, 2001). In the 2000-01 season only, four sets of 7.6 by $15.2 \mathrm{~cm}$ nylon mesh bags (Delnet Applied Extrusion Technologies Inc., 601 Industrial Drive, Middletown, Del. USA) containing 50 seeds each of four weed species were placed directly under the mulch in the center of the bed of each plot on 15 Oct. 2000.

Seed of weed species used to measure germination directly under the tarp included: California burclover (Medicago polymorpha), and prostrate knotweed (Polygonum aviculare) seed that was greenhouse propagated from parent stock gathered in fields near Salinas, Calif., and little mallow (Malva parviflora), and redstem filaree (Erodium cicutarium) were purchased (Valley Seed, Fresno). One set of seed bags was removed from the plots at each of the following dates: 30 Nov. 2000, 31 Jan., 29 Mar., and 24 May 2001. At the time of each seed bag retrieval, the seed bags were cut open, separated by species and the number of germinated and ungerminated seeds were counted and recorded. For season one, weed densities in the entire plot were recorded by species on the same dates as seed bags were removed. For season two, weeds were seeded in the middle (lengthwise) $3.4 \mathrm{~m}$ of each plot, before mulch installation. Species were the same as those packaged in seed bags for season one. The plots were hand-weeded after each density or weed biomass measurement.

Watsonville organic site. The certified organic plot area at Monterey Bay Academy, near Watsonville, Calif., had been used for organic production since 1995, with lettuce, broccoli and cauliflower as the primary crops. Soil preparation, bed width, plant spacing, drip irrigation and plastic mulch treatments were all identical to those described for the conventional trial, except that the plots were $7.6 \mathrm{~m}$ long. Plant nutrients were supplied by blood meal $(14 \% \mathrm{~N}$, Calif. Organic Fertilizers, Inc., Fresno) applied at $4 \mathrm{~g} /$ plant to the beds just prior to planting. Phytamin 800 (7\% N, Calif. Organic Fertilizers, Inc., Fresno), a derivative of blood and feather meal, was injected into the drip irrigation each week throughout the growing season at a rate of $18.7 \mathrm{~L} \cdot \mathrm{ha}^{-1}$. Cultivars, planting and harvest dates are listed in Table 1.

Every 6 to 8 weeks, depending on the weather and weed growth rate, the mulches were removed to collect weed biomass samples. Weeds in each plot from two random $0.25-\mathrm{m}^{2}$ quadrats on the bed top were sampled, separated by species and weighed. After each weed sample collection, remaining weeds in the plot outside the sample area were removed by hand, and then the mulch was reinstalled. Plant canopy diameter and yield data were collected as described above from 20 sample plants/plot. The white/black 1 plastic used in year 1 , was replaced by a white/black 2 laminated mulch for this trial only (White/Black, LECO Industries, St-Laurent, Quebec). The strawberry cultivar, 'Diamante' was included in both seasons. Planting and harvest dates are listed in Table 1.

Salinas organic site. An additional trial was initiated in the 2001-02 season on the organic research land at the Spence USDA research Farm in Salinas, Calif. This land was certified as organic in 1998, and from 1998 to 2001, had been cropped with cole crops, lettuce and cover crops. Before trial initiation, compost was applied at $56 \mathrm{t} \cdot \mathrm{ha}^{-1}$ and incorporated to a depth of $15 \mathrm{~cm}$. The compost consisted of $35 \%$ yard and salad packing plant waste, and $65 \%$ straw, manure and clay. The carbon to nitrogen ratio of the 8- to 10-week-old compost was 15. After formation of $1.3 \mathrm{~m}$ beds, two drip tapes were installed as described in the previous studies. Organic fertilizer pellets (7-5-7, Calif. Organic Fertilizer, Inc., Fresno) were applied to the beds at a rate of $280 \mathrm{~kg} \cdot \mathrm{ha}^{-1}$, and weekly Phytamin 800 applications were made as described in the Watsonville organic section.

The same colored mulches as those used in the Watsonville conventional trials, were established in plots that were one bed wide $\times 9.5 \mathrm{~m}$ long. Temperature recorders, identical to those used in Watsonville, were placed in each plot of the second block, and the hourly soil temperature measured for the period from 8 Dec. 2001 through 1 Sept. 2002. Weed control, strawberry canopy diameters and yield measurements were similar to that described for the second year of the Watsonville organic trial. Plant diameters were measured on 20 Mar. and 20 May 2002. Fruit was harvested from 9Apr. through 29Aug. 2002 and sorted as described above.

Greenhousestudy. Agreenhouse experiment was conducted to measure the effect of mulch color on weed growth under the mulch. Pots of $10 \mathrm{~cm}$ in diameter were filled with potting mix and seeded with four weed species; common chickweed (Stellaria media [L.] Vill.), annual bluegrass (Poa annua L.), corn spurry (Spergula arvensis L.), and persian speedwell (Veronica persica Poir.). The common chickweed, and annual bluegrass seed were obtained from Valley Seed, Fresno. Corn spurry and persian speedwell seed were obtained from Herbiseed, Twyford, U.K. These species were selected because they were the predominate weeds at the Watsonville organic production site. The pots were divided into quarters, and seed of each species were planted in each quarter. After emergence, plants were thinned at the one- to two-leaf stage, to one per quarter of each species, leaving four plants per pot for each species. After thinning, the pots were covered using the same mulch colors as were used in the Watsonville and Salinas field trials, with an untarped pot as the control. The pots were watered twice weekly by drip irrigation. After $31 \mathrm{~d}$, the plants were harvested and dry weights determined. A randomized complete block design was used and each treatment was replicated four times. The experiment was repeated twice in time, with the first iteration conducted in a greenhouse and the second iteration on outdoor benches. Rather than directly seeding weeds in the second iteration, weed seeds were first germinated in greenhouse plug trays, then one- to two-leaf plants were transplanted into pots in the same arrangement as before.

Effect of mulch on weed germination. A laboratory experiment was conducted to isolate the effect of mulch color on weed seed germination. Fifty seeds each of annual bluegrass, common chickweed, corn spurry, and persian speedwell were placed on Whatman No. 1 filter paper in clear plastic petri dishes $(15 \mathrm{~mm}$ in height and $100 \mathrm{~mm}$ in diameter). Distilled water $(0.5 \mathrm{~mL})$ was added followed by $0.5 \mathrm{~mL}$ of $2 \%$ Captan 50WP (Zeneca Agricultural Products, Wilmington, Del.) ( $N$-Trichloromethylthio-4cyclohexane-1,2-dicarboximide) solution to control seedling pathogens.

Treatments included the same mulch colors as those used in the field trials, and $24 \mathrm{~cm}^{2}$ samples of these films were used to enclose the petri dishes so that all light was excluded except that transmitted through the plastic film. An uncovered petri dish served as a control. 
The plates were incubated in a Percival E-36L growth chamber (Percival Scientific Inc., Perry, Iowa) set for $10 \mathrm{~h}$ darkness and $14 \mathrm{~h}$ light at 15 and $23{ }^{\circ} \mathrm{C}$, respectively. Treatments were replicated four times and arranged in a complete randomized design. Germination counts were made in a darkroom under a hand-held black light ( $15.3 \mathrm{~cm}, 4 \mathrm{~W}$ Rave Beam, Adams Apple Dist. L.P. Glenview, Ill.) and a dissecting microscope. Germinated seeds were identified, counted and recorded; if necessary the plates were wetted with 0.5 to $1 \mathrm{~mL}$ deionized water, then returned to the growth chamber. Seed germination was monitored weekly for four weeks. The first study iteration was conducted in July 2002 , and the second iteration was conducted September 2002.

Mulch light transmittance. Light transmitted through the plastic mulch treatments used in all the experiments was measured using a Fieldspec Handheld spectroradiometer (Analytical Spectral Devices, Inc., Boulder, Colo.). The light sensing, fiber optic probe of the spectroradiometer was fitted with a nylon adaptor to the light receiving port (LI-1800-12; LI-COR,
Inc., Lincoln, Neb.) of an external integrating sphere. Ten $5-\mathrm{cm}$ squares were cut from various areas along the widths of the plastic films to account for variability within the films. Light from the integrating sphere's illuminator was transmitted through ten samples of each film for a 215 milliseconds measurement period. For each sample the spectroradiometer made 10 sequential measurements and averaged them.

Data analysis. All datasets were tested for normality and if necessary subjected to transformation before analysis of variance testing. If an $\mathrm{F}$ test indicated significant variation between treatments at the $5 \%$ probability level, the data were tested for homogeneity of variance between treatments and additivity between factors (e.g., block, time, location, etc.).

Data were analyzed using the SAS general linear model (GLM) procedure (SAS Institute, Cary, N.C. ). Nonsignificant interaction were determined by performing a multiway analysis of variance classifying the factors, time and location, to determine that variation between years and locations was additive (Steel et al., 1997). Fisher's protected least significant difference

Table 2. Photosynthetically active radiation (PAR, 400 to $700 \mathrm{~nm}$ ) transmission through plastic mulches, and effect of mulch on soil temperature degree-hours under each mulch.

\begin{tabular}{|c|c|c|c|}
\hline \multirow{2}{*}{$\begin{array}{l}\text { Mulch } \\
\text { color }\end{array}$} & \multirow{2}{*}{$\begin{array}{l}\text { PAR transmitted } \\
\left(\mathrm{W} \cdot \mathrm{nm}^{-1} \cdot \mathrm{m}^{-2}\right)\end{array}$} & Salinas $^{\mathrm{y}}$ & Watsonville $^{x}$ \\
\hline & & \multicolumn{2}{|c|}{$10^{\circ} \mathrm{C}$ degree-h $(1,000)^{\mathrm{w}}$} \\
\hline No mulch & --- & 5.7 & 4.3 \\
\hline Clear & $180.5 \mathrm{a}^{\mathrm{v}}$ & 11.0 & 4.9 \\
\hline Blue & $61.1 \mathrm{~b}$ & 6.9 & 4.7 \\
\hline Red & $19.3 \mathrm{c}$ & 6.5 & 5.3 \\
\hline Brown & $10.9 \mathrm{~d}$ & 5.2 & 4.8 \\
\hline Green & $10.6 \mathrm{~d}$ & 6.3 & 4.4 \\
\hline Yellow & $10.2 \mathrm{~d}$ & 4.5 & 4.7 \\
\hline White/black $1^{\mathrm{u}}$ & $2.6 \mathrm{e}$ & 6.2 & 4.5 \\
\hline White/black $2^{\mathrm{t}}$ & $1.7 \mathrm{ef}$ & --- & --- \\
\hline Black & $0.1 \mathrm{f}$ & 4.4 & 5.4 \\
\hline
\end{tabular}

zTransmission values were measured with a Fieldspec Handheld spectroradiometer (Analytical Spectral Devices, Inc., Boulder, Colo.), and an external integrating sphere (LI-1800-12; LI-COR, Lincoln, Neb.). y Data is from 2002 trial.

'Data is from 2001 trial.

wSoil temperatures measured at $2.5 \mathrm{~cm}$ deep from time of mulch installation of temperature recorders through first harvest in 1,000's of degree hours.

"Values sharing the same letter are not significantly different at the $5 \%$ level of probability according to Fisher's protected least significant difference test.

"White/black laminated mulch used in all trials, except the Watsonville organic trial in year 2.

tWhite/black laminate mulch used only in the Watsonville organic trial in year 2.

Table 3. Weed germination in the laboratory and field, under colored plastic mulches, and weed growth in pots under colored mulches.

\begin{tabular}{lccc}
\hline & \multicolumn{2}{c}{ Germination (\%) } & \multicolumn{2}{c}{ Weed control $^{\mathrm{z}}$} \\
\cline { 2 - 4 } Treatment & Laboratory & Field $^{\mathrm{y}}$ & $(\%)$ \\
\hline No mulch & $72.4 \mathrm{a}^{\mathrm{x}}$ & $32.0 \mathrm{ab}$ & $0.0 \mathrm{a}$ \\
Clear & $67.0 \mathrm{~b}$ & $46.0 \mathrm{a}$ & $64.3 \mathrm{~b}$ \\
Blue & $70.0 \mathrm{ab}$ & $19.0 \mathrm{ab}$ & $97.4 \mathrm{c}$ \\
Red & $67.4 \mathrm{~b}$ & $27.0 \mathrm{ab}$ & $98.5 \mathrm{c}$ \\
Brown & $67.0 \mathrm{~b}$ & $23.0 \mathrm{ab}$ & $99.6 \mathrm{c}$ \\
Yellow & $66.3 \mathrm{~b}$ & $32.0 \mathrm{ab}$ & $99.0 \mathrm{c}$ \\
Green & $67.4 \mathrm{~b}$ & $13.0 \mathrm{~b}$ & $99.6 \mathrm{c}$ \\
White & $69.1 \mathrm{ab}$ & $22.0 \mathrm{ab}$ & $99.6 \mathrm{c}$ \\
Black & $53.6 \mathrm{c}$ & $28.0 \mathrm{ab}$ & $100.0 \mathrm{c}$ \\
\hline
\end{tabular}

${ }^{\mathrm{z}}$ The values listed are based on the mean weights of annual bluegrass, common chickweed, corn spurry and Persian speedwell grown under the respective plastic mulch. The relative weed control (RWC) was calculated by the formula: $\mathrm{RWC}=[(\mathrm{NM}-\mathrm{CM}) / \mathrm{NM}] \times 100$ where $\mathrm{NM}$ is the dry weights of the no mulch pot, $36.04 \mathrm{mg}$, and CM is dry weight per plant of the weeds grown under mulch.

${ }^{y}$ Annual bluegrass, common chickweed, corn spurry and persian speedwell germination pooled from two experiments.

${ }^{\mathrm{x}}$ California burclover, little mallow, redstem filaree and prostrate knotweed germination in the $2000-01$ Watsonville experiment.

"Values in the same column sharing the same letter are not significantly different at the $5 \%$ level of probability according to Fisher's protected least significant difference test.
(LSD) test was used for mean separation. Data were pooled when experiment by treatment interactions were not significant. Simple linear regression was used to establish the relationship between PAR transmissions through the plastic mulches and weed growth below the mulches (Geng, 1997). Mulch PAR values were classified as the independent variable and weed control as the dependent variable; SigmaPlot 2001 (SPSS Inc. Chicago, Ill.) was used to determine the regression equation.

\section{Results}

Mulch effect on soil warming and light transmission. Soil warming effects caused by the various colored mulches varied between locations. Degree-hours accumulated over 10 ${ }^{\circ} \mathrm{C}$ were highest under clear mulch at Salinas (Table 2). At Watsonville the black and red mulch accumulated more degree-hours than the clear. The average daily solar radiation during the trial period was $601.5 \mathrm{~J} \cdot \mathrm{cm}^{-2} / \mathrm{d}^{-1}$ at Salinas, and $538.0 \mathrm{~J} \cdot \mathrm{cm}^{-2} / \mathrm{d}^{-1}$ at Watsonville (Salinas South and Watsonville weather station data, respectively; http://www.ipm.ucdavis. edu/weather/weather1.html). Differences in the average daily solar radiation for the respective periods at each location were likely due to greater cloud cover or fog at Watsonville than Salinas. Clear, blue and red mulch allowed the greatest amount of PAR (400 to $700 \mathrm{~nm}$ ) to be transmitted through the mulch (Table 2). The mean separation reveals the following groups ranking from greatest to least PAR transmission: 1) clear, 2) blue, 3) red, 4) brown, green, yellow, 5) white/black, 6) black.

Evaluation of mulch on weed growth and germination. There were small differences in annual bluegrass, common chickweed, corn spurry and persian speedwell germination, among the petri dishes covered with the various mulch colors, but mulch color had large effects on control of weed growth(Table 3). Fewer seeds germinated in petri dishes covered by the black mulch than the other mulch colors, however, the range of germination percentages between black and blue, lowest and highest, respectively, was only $16.4 \%$. All colored mulches, except blue and white, reduced the total germination compared to the uncovered dishes.

Germination of California burclover, little mallow, redstem filaree and prostrate knotweed in seedbags that had been placed under the mulches in the field differed little between mulch colors. For example, the difference in germination percentage between black and clear were $18 \%$ in the field compared to $13 \%$ in the lab (Table 3). However, overall germination in the lab was much higher than in the field. This may have been due to more ideal moisture conditions in the lab than the field and the fact that weed species differed in the two experiments.

Weed control in field experiments. Colored mulches improved weed control compared to no mulch or clear mulch (Table 4). Of the colored mulches, blue and red allowed the most weed growth, while yellow and green, brown, white and black-mulched plots had weed control ratings in the $76 \%$ to $100 \%$ range.

The organic production trials had much 
higher weed populations and greater species diversity than the conventional trials. Weed species collected from the organic plots include the following in order of abundance in biomass: persian speedwell, common chickweed, prostrate knotweed, corn spurry, annual bluegrass, hairy nightshade, creeping woodsorrel (Oxalis corniculata L.), black nightshade (Solanum nigrum L.), pineappleweed (Matricaria matricarioides (Less.) Poter), shepherd's-purse, redstem filaree, California burclover, crimson clover (Trifolium incarnatum L.), little mallow, common groundsel, volunteer strawberry, toad rush (Juncas bufonius L.), annual sowthistle and nettleleafgoosefoot (Chenopodium murale L.). Analysis of the species composition in the samples of total weed biomass by a principal components (PC-ORD, proc. princomp) analysis and multiple analyses of variance did not suggest that mulches affected the growth and/or germination of one species differently than another (data not shown). Therefore total weed control is reported rather than control of individual weed species.

Strawberry plant growth and fruit yield. Strawberry plants in the clear mulch plots were the largest in the early season growing period (data not shown). Plants in the white-mulched plots had smaller plant canopy diameters than in the other treatments (Table 5). Yellow and brown-mulched plots had smaller early season plants than the other colored mulches. Variation in strawberry plant canopies for the latest measurement dates (April or May) were less than for the earlier dates with smaller plants in red and uncovered plots than in other mulched plants except white/black (data not shown).

Conventional production marketable yield totals were pooled for the 2000-01 and 2001-02 seasons. The early season growth of plants in the clear plots translated into higher total marketable yields for those plants, producing more berries than the other treatments. All other treatments had similar yields except the white/black-mulched plots, where yields were lower (Table 6).

Organic-production marketable fruit yield for the two locations differed inversely between black and clear-mulched plots. Clear-mulched plots in the Watsonville trial had the lowest mulched plot yield and black-mulched plots ranked among the highest. However in Salinas, black-mulched plot yield was among the lowest and clear produced the most marketable berries (Table 6). Differences in soil temperatures for clear mulch at Salinas and Watsonville may explain this difference (Table 2). Yellow and white-mulched plots, to a lesser extent, showed an inverse response to location similar to the black-mulched plots.

\section{Discussion}

We hypothesize that light transmittance and degree-hour accumulation are responsible for variation in weed biomass differences under the mulches. Soil warming is necessary to maximize strawberry production, therefore, light transmittance is one factor that can be more readily manipulated to develop a weed control strategy. Germination and growth of weeds are two processes that are influenced by light qual-

Table 4. The effect of plastic mulch color on weed control in conventional and organic production strawberries.

\begin{tabular}{|c|c|c|c|c|}
\hline \multirow[b]{3}{*}{ Treatment } & \multicolumn{4}{|c|}{ Control (\%) } \\
\hline & \multicolumn{2}{|c|}{ Conventional $^{\mathrm{z}}$} & \multicolumn{2}{|c|}{ Organic $^{y}$} \\
\hline & $2000-01$ & $2001-02$ & $2000-01$ & $2001-02^{x}$ \\
\hline No mulch & $0.0 \mathrm{c}^{\mathrm{w}}$ & $0.0 \mathrm{f}$ & $0.0 \mathrm{~b}$ & $0.0 \mathrm{e}$ \\
\hline Clear & $44.0 \mathrm{~b}$ & $-14.0 \mathrm{~g}$ & $-93.3 \mathrm{c}$ & $-55.0 \mathrm{f}$ \\
\hline Blue & $50.1 \mathrm{~b}$ & $43.0 \mathrm{e}$ & $33.2 \mathrm{~b}$ & $61.9 \mathrm{e}$ \\
\hline Red & $77.6 \mathrm{a}$ & $58.5 \mathrm{~d}$ & $72.9 \mathrm{a}$ & $84.8 \mathrm{~d}$ \\
\hline Yellow & $96.3 \mathrm{a}$ & $76.0 \mathrm{c}$ & $92.8 \mathrm{a}$ & $98.4 \mathrm{c}$ \\
\hline Brown & $86.0 \mathrm{a}$ & $79.8 \mathrm{bc}$ & $86.9 \mathrm{a}$ & $98.7 \mathrm{bc}$ \\
\hline Green & $96.6 \mathrm{a}$ & $75.7 \mathrm{c}$ & $84.8 \mathrm{a}$ & $99.4 \mathrm{ab}$ \\
\hline White/black & $97.5 \mathrm{a}$ & $89.0 \mathrm{a}$ & $80.9 \mathrm{a}$ & $99.8 \mathrm{a}$ \\
\hline Black & $98.0 \mathrm{a}$ & $97.6 \mathrm{a}$ & $73.9 \mathrm{a}$ & $100.0 \mathrm{a}$ \\
\hline
\end{tabular}

${ }^{2}$ The values listed are the based on the season long weed densities in 2000-01 or season-long weed biomasses in 2001-02. Relative weed control was calculated by the formula percent control $=[(\mathrm{NM}-\mathrm{CM}) / \mathrm{NM}] \times$ 100 where NM is the density or biomass of the no mulch plot, $4.1 \mathrm{~m}^{2}$ or $3.4 \mathrm{~g} \cdot \mathrm{m}^{-2}$, and CM is the density or weight of the weeds grown under mulch.

${ }^{y}$ The values listed are the based on the season-long weed biomasses. Relative weed control was calculated as defined above, where NM is the biomass of the no mulch plot, $820 \mathrm{~g} \cdot \mathrm{m}^{-2}$ in $2000-01$, and $502 \mathrm{~g} \cdot \mathrm{m}^{-2}$ in $2001-02$.

xPooled Salinas and Watsonville data.

wValues in the same column sharing the same letter are not significantly different at the $5 \%$ level of probability according to Fisher's protected least significant difference test.

Table 5. The effect of mulch color on conventional strawberry canopy diameters.

\begin{tabular}{llcccc}
\hline & \multicolumn{2}{c}{ Conventional } & & \multicolumn{2}{c}{ Organic } \\
\cline { 2 - 3 } \cline { 5 - 6 } Treatment & April 2001 & March 2002 & & April 2001 & March 2002 \\
\hline No mulch & $31.0 \mathrm{e}^{z}$ & $17.6 \mathrm{~d}$ & & $26.5 \mathrm{bc}$ & $9.8 \mathrm{~b}$ \\
Clear & $33.3 \mathrm{abc}$ & $20.0 \mathrm{a}$ & & $26.4 \mathrm{c}$ & $13.2 \mathrm{a}$ \\
Blue & $34.1 \mathrm{a}$ & $18.3 \mathrm{~cd}$ & & $29.3 \mathrm{ab}$ & $12.2 \mathrm{a}$ \\
Red & $33.9 \mathrm{a}$ & $19.1 \mathrm{bc}$ & & $30.8 \mathrm{a}$ & $12.2 \mathrm{a}$ \\
Yellow & $32.5 \mathrm{bcd}$ & $17.8 \mathrm{~d}$ & & $30.4 \mathrm{a}$ & $10.0 \mathrm{~b}$ \\
Brown & $31.5 \mathrm{de}$ & $19.6 \mathrm{ab}$ & & $31.0 \mathrm{a}$ & $12.0 \mathrm{a}$ \\
Green & $33.5 \mathrm{ab}$ & $19.0 \mathrm{bc}$ & & $30.9 \mathrm{a}$ & $12.7 \mathrm{a}$ \\
White/black & $32.2 \mathrm{~cd}$ & $14.9 \mathrm{e}$ & & $29.9 \mathrm{a}$ & $9.7 \mathrm{~b}$ \\
Black & $31.5 \mathrm{de}$ & $18.8 \mathrm{bc}$ & & $29.3 \mathrm{ab}$ & $12.1 \mathrm{a}$ \\
\hline
\end{tabular}

${ }^{2}$ Data from Watsonville site.

'Values in the same column sharing the same letter are not significantly different at the $5 \%$ level of probability according to Fisher's protected least significant difference test.

Table 6. The effect of mulch color on conventional strawberry fruit yields.

\begin{tabular}{lccc}
\hline & & \multicolumn{2}{c}{ Yield $\left(\mathrm{kg} \cdot \mathrm{m}^{-2}\right)$} \\
\cline { 2 - 4 } Treatment & \multicolumn{2}{c}{ Conventional } & \multicolumn{2}{c}{ Organic } \\
\cline { 2 - 4 } No mulch & $10.5 \mathrm{~b}^{\mathrm{x}}$ & $1.1 \mathrm{c}$ & $0.9 \mathrm{c}$ \\
\cline { 2 - 4 } Clear & $11.9 \mathrm{a}$ & $1.3 \mathrm{bc}$ & $1.2 \mathrm{a}$ \\
Blue & $10.0 \mathrm{bc}$ & $1.7 \mathrm{ab}$ & $1.0 \mathrm{bc}$ \\
Red & $10.5 \mathrm{~b}$ & $1.9 \mathrm{a}$ & $1.1 \mathrm{ab}$ \\
Yellow & $10.3 \mathrm{~b}$ & $1.7 \mathrm{ab}$ & $1.0 \mathrm{bc}$ \\
Brown & $10.1 \mathrm{~b}$ & $2.0 \mathrm{a}$ & $1.1 \mathrm{ab}$ \\
Green & $10.5 \mathrm{~b}$ & $1.9 \mathrm{a}$ & $1.1 \mathrm{ab}$ \\
White/black & $9.2 \mathrm{c}$ & $2.0 \mathrm{a}$ & $1.0 \mathrm{bc}$ \\
Black & $10.8 \mathrm{~b}$ & $2.2 \mathrm{a}$ & $0.9 \mathrm{c}$
\end{tabular}

${ }^{2}$ Data from Watsonville site pooled for 2000-01 and 2001-02 seasons.

'Data from Watsonville site pooled for 2000-01 and 2001-02 seasons.

${ }^{x}$ Values in the same column sharing the same letter are not significantly different at the $5 \%$ level of probability according to Fisher's protected least significant difference test.

Table 7. Parameters used to evaluate the relationship between PAR transmitted through colored mulches and weed control. ${ }^{\mathrm{T}}$

\begin{tabular}{lcccc}
\hline Production system & Season & Y & $\mathrm{a}$ & $r^{2}$ \\
\hline Conventional & $2000-01$ & 92.2 & -0.31 & 0.75 \\
Conventional & $2001-02$ & 84.0 & -0.56 & 0.94 \\
Organic & $2000-01$ & 91.2 & -1.01 & 0.98 \\
Organic $^{\mathrm{y}}$ & $2001-02$ & 105.7 & -0.87 & 0.99 \\
\hline
\end{tabular}

${ }^{2}$ The equation used to evaluate the relationship between PAR and weed control was: $\mathrm{W}=\mathrm{Y}+\mathrm{ax}$, where $\mathrm{W}$ is the weed control (\% of no mulch control), $\mathrm{Y}$ is the weed control (\%) at $0 \mathrm{PAR}$, and a is the slope of the regression, and $\mathrm{x}$ is the PAR transmittance $\left(\mathrm{W} / \mathrm{nm} / \mathrm{m}^{2}\right)$.

'Pooled weed control data from the Salinas and Watsonville 2001-02 organic experiments.

ity and quantity (Bliss and Smith, 1985, Ellis et al., 1989). However, no clear relationship between mulch light transmission and weed germination was observed with the exception 
that germination was generally reduced under black mulch, compared to the control (Table $3)$. If weed control from mulches were based solely on inhibition of seed germination, then poor weed control would result. The mulch color most inhibitory to weed germination, black, only reduced weed seed germination by $4 \%$ to $18.8 \%$ compared to the uncovered control (Table 3 ). The best possible weed control strategy with colored tarps is to inhibit the transmission of PAR.

The effect that mulch color has on weed growth appears to be very consistent with the weed control ratings from the organic production plots. Using PAR transmission values (Table 2) as fixed points, a regression line was fitted to the relative weed control from all field experiments using a straight-line model. The following equation, defines the parameters for the regression $\mathrm{W}=\mathrm{Y}+\mathrm{ax}$, where $\mathrm{W}=$ relative weed control as a percentage of the no mulch control, $\mathrm{Y}=$ weed control at $0 \mathrm{PAR}, \mathrm{a}=$ the slope of the regression, and $\mathrm{x}=$ PAR transmittance in $\mathrm{W} / \mathrm{nm} / \mathrm{m}^{2}$. The coefficient of determination $\left(r^{2}\right)$ for the regression is 0.75 to 0.99 ; indicting that $75 \%$ to $99 \%$ of the variation in weed control is a direct response to the quantity of PAR transmitted through the mulch (Table 7). The $r^{2}$ for the first year of the conventional trial was 0.75 , and may have been lower due to the fact that weed control in that trial was based on weed density counts, while in the other trials weed control was based on weed biomass data. Weed density counts are partially sensitive to the effects of mulch color on weed germination, and germination is a less reliable indicator of mulch color effect on weed control than weed biomass, which reflects weed growth.

Growth of the weeds in the Watsonville conventional production trial responded similarly to the mulch treatments as the weeds found in the organic trials. The mean separation of the biomass totals (Table 4) provides groupings very similar to the biomass samples collected from the organic plots despite the fact that the weed species and densities varied. These results suggest that weeds respond similarly to limitations of PAR by plastic mulches.

Weeds grew in four different environments: 1) weeds that grew under the mulch towards the unfiltered light coming through the plant hole, 2) weeds that grew in the plant hole, 3 ) weeds that grew on the bed-tops under clear mulch and 4) weeds that grew on bare plots. More weeds were found in the bare plots than the clear-mulched plots in the Watsonville trial (Table 4), which suggests that clear mulch suppressed weed seed germination as seen in the lab experiment (Table 3). However, weeds under the clear mulch consisted of fewer, but larger individuals (data not shown). Clearmulch may suppress germination of weeds such as common chickweed and corn spurry, species that are sensitive to warm conditions under the mulch during germination(Buhlerand Hoffman, 1999; Turkington et al., 1980). However, our results demonstrate that clear mulch provides poor weed control (Table 4), which suggests that suppression of weed growth by colored mulch is more important for weed control than suppression of weed germination.
Clear and black mulches typify the two processes responsible for sequestering thermal energy below the plastic mulch. Trapping radiant energy with clear mulch to create a greenhouse effect is possibly more efficient when the light waves are not scattered or filtered by water droplets in clouds or fog. Under cloud cover there is an overall reduction in irradiance at all wavelengths, but the greatest reduction is infrared $(>700 \mathrm{~nm}$ ) wavelength transmittance (Gates, 1965). Conceivably, absorption and conduction of scattered light energy or smaller wavelengths such as ultraviolet and visible light, by black mulch is more efficient than the process by which clear mulch traps solar energy in cloudy locations such as Watsonville.

In the organic production trials, weed competition and effects of weed removal in some of the treatments may have reduced yields. Although weeds were removed at six to eight week intervals, injury to strawberry plants caused by weed removal may also have had deleterious effects on yields. Additionally, lack of soil fumigation in the organic trials may have resulted in greater disease incidence, and lower yields. Clear-mulched plots were in the lowest yielding group at Watsonville but in the highest yielding group at Salinas. Inversely, blackmulched plots were in the highest yield group in Watsonville and lowest in Salinas (Table 6 ). These results support the theory that soil warming increases strawberry yield (Voth and Bringhurst 1990) and that efficiency of the heat sequestration may differ depending on cloudy or foggy climatic conditions as previously mentioned. Colored plastic mulches, except for white/black and yellow/brown laminated, combine the heat sequestration methods. Soil warming effects of colored treatments varied by location (Table 2); red accumulating the most degree hours at Watsonville, and blue at Salinas. Without replication of the temperature data, plant growth and yield data must be considered for evaluating soil-warming benefits created by the mulch treatments.

Colored mulch treatments at the conventional site at Watsonville (Table 5) had smaller strawberry plants than clear early in the season. Late season growth in the colored mulch plots, except for red and white, resulted in similar sized plants as the clear tarp plants by May (data not shown), but yields in the colored tarps were lower throughout the season than clear tarp yields. White-mulched plots produced neither large plants nor high yield in this trial; probably the result of limited soil warming benefits offered by that mulch. The light reflection qualities of laminated mulches did not significantly benefit strawberry plant growth or yield.

Grower decisions on mulch color should be based on two factors: weed pressure and soil warming requirements. If weed pressure is low or fumigants that provide effective weed control can be used, clear mulch generally provides optimal soil warming, which translates into higher marketable yield in California's coastal production areas. Where post-plant weed control is necessary due to no fumigation, or fumigation at rates too low to control weeds, plastic film that blocks PAR radiation, but transmits the remaining spectra (green and brown mulches in this study) are recommended. Cloudy or foggy conditions warrant the use of black mulch for improved heat sequestration under such conditions, but care should be taken to limit air spaces between black mulch and the soil surface to enhance heating of the soil. Regardless of whether the black, brown, green, white oryellow mulches are chosen - the primary consideration should be to create conditions for optimum strawberry yield. Our data indicate that strawberry plants are very sensitive to mulch color, while any tarp that limits PAR will control weeds.

\section{Literature Cited}

Bliss, D. and H. Smith. 1985. Penetration of light into soil and its role in the control of seed germination. Plant Cell Environ. 8:475-483.

Buhler, D.D. and M.L. Hoffman. 1999. Andersen's guide to practical methods of propagating weeds and other plants. Allen Press, Lawrence, Kans.

California Strawberry Commission. 2001. 2001 California strawberry season begins. 27 Aug. 2003. <hppt://www. calstrawberry.com/news/viewpress.asp>.

Ellis, R.H., T.D. Hong, and E.H. Roberts. 1989. Response of seed germination in three genera of Compositae to white light of varying photon flux density and photoperiod. J. Expt. Bot. 40:13-22.

Fennimore, S.A. 2005. Weed control in organic strawberry. In: S. Sweazy (ed.). Organic strawberry production manual. Univ. Calif. Div. Agr. Nat. Resour. (in press).

Galletta, G. and D. Himelrick (eds.). 1990. Strawberry management, p. 83-156. In: Small fruit crop management. Prentice Hall, Englewood Cliffs, N.J.

Gates, D.M. 1965. Radiant energy, its receipt and disposal. Meteorol. Monogr. 6(28):1-26.

Geng, S. 1997. Simple regression and correlation, p.178-214. In: Biometrics in agricultural science. Kendall/Hunt, Dubuque, Iowa

Locascio, S.J., J.P. Gilreath, D.W. Dickson, T.A. Kucharek, J.P. Jones, and J.W. Noling. 1997. Fumigant alternatives to methyl bromide for plastic-mulched tomato. HortScience 32:1208-1211.

National Agricultural Statistics Service. 2002. Fruits, tree nuts, and horticultural specialties. USDA-NASS, Wash., D.C.

Olson, S.M. 2002. Mulching, p. 25-28. In: S.M. Olson and D.N. Maynard (eds.). Vegetable production guide for Florida. Univ. Fla. Ext.

Steel, R.G., J.H. Torrie, and D.A. Dickey. 1997. Multiple comparisons and analysis of variance II: multiway classifications, p.178-252. In: Principles and procedures of statistics, a biometric approach. McGraw Hill, San Francisco.

Teasdale, J.R. and C.L. Mohler. 2000. The quantitative relationship between weed emergence and the physical properties of mulches. Weed Sci. 48:385-392.

Turkington, R., N.C. Kenkel, and G.D. Franco. 1980. The biology of Canadian weeds 42. Stellaria media (L.) Vill. Can. J. Plant Sci. 60:981-992.

University of California. Integrated Pest Management. Disease model database. Fire blight. Available online at: http://www.ipm.ucdavis.edu/DISEASE/DATABASE/fireblight.html.

United Nations Environmental Programme. 1998. Assessments of alternatives to methyl bromide. Methyl bromide technical options committee. United Nations Environmental Programme, Ozone Secretariate, Nairobi, Kenya.

U.S. Department of Agriculture. 1999. Crop profile for strawberries in California. Office of Pest Mgt. Policy andPesticide ImpactProg. http://pestdata.ncsu.edu/cropprofiles/docs/castrawberries.html.

Voth, V. and R.S. Bringhurst. 1959. Polyethylene over strawberries. Calif. Agr. 13(2):14-15.

Voth, V. and R.S. Bringhurst. 1962. Early mulched strawberries. Calif. Agr. 16(2):187-197.

Voth, V. and R.S. Bringhurst. 1990. Culture and physical manipulation of California strawberries. Hort. Sci. 25(8):889-892.

Wilhelm, S. and H. Thomas 1952. Solanum sarrachoides, an importantweed host to Verticillium albo-atrum (abstract). Phytopathology. 42:519-520.

Wilhelm, S. and A. Paulus. 1980. How soil fumigation benefits the California strawberry industry. Plant Dis. 64:265-270. 